\title{
The Effect of the Time of Fruit Harvest on Flower Formation and Carbohydrate Contents in Shoots of Wase Satsuma Mandarin Trees
}

\author{
Daijiro Yahata*, Kazunori Matsumoto and Kosaku Ushijima \\ Fukuoka Agricultural Research Center, Chikushino 818-8549, Japan
}

\begin{abstract}
The effect of the time of fruit harvest and that of fruit removal in early-July on flower formation and carbohydrate contents were investigated in Wase satsuma mandarin trees. In the spring shoots of the bearing trees, the flower induction seemed to be retarded in comparison with the summer shoots in the July-defruited trees. Both in the defruited trees and the early harvested (mid-Oct.) trees, flower formation occurred earlier and increased markedly higher by mid-March in comparison with the customary harvested (mid-Nov.) and late harvested (mid-Dec. or mid-Jan.) trees. Starch accumulation in the shoots seemed to parallel flower induction. Our data in Wase satsuma mandarin indicate a clear effect of the fruit harvest before November on both flower formation and starch accumulation.
\end{abstract}

Key Words: carbohydrate, early fruit removal, flower formation, harvest time, satsuma mandarin.

\section{Introduction}

Alternate bearing is a large problem for the stable production of satsuma mandarin (Citrus unshiu Marc.). It is important to clarify the inhibitory effect of fruit load on flower formation in order to establish the countermeasure for the alternate bearing. Flower induction in satsuma mandarin trees occurs in response to low temperature (Garcia-Luis et al., 1992; Inoue, 1990). The most important period for the flower induction is about mid-November, as the number of flowers in the following spring is markedly decreased by defoliation, and increased by ringing or defruiting before mid-November (Agusti et al., 1992; Garcia-Luis et al., 1986; Iwahori et al., 1990; Iwasaki, 1959). However, the effects of fruit load and harvest timing on the progression of flower formation from harvest to the following spring have not been sufficiently explored. In a previous study (Yahata et al., 2004) with the experimental method using excised shoots, we reported that the number of flowering shoots formed when the buds were forced to sprout rapidly increased from January to March in the very-early maturing cultivar harvested in late-October.

In this study, we examined the effect of harvest timing of heavy fruit load trees before or after mid-November on the progression of flower formation in the early maturing cultivar during winter rest period. In addition, starch and sugar contents in the shoots were quantified to seek the control mechanism of flower formation.

Received; November 19, 2004. Accepted; July 21, 2005.

* Corresponding author (E-mail: yahatad@farc.pref. fukuoka.jp).

\section{Materials and Methods}

\section{Plant materials}

'Okitsu Wase' (C. unshiu Marc. var. praecox Tanaka) trees grafted on trifoliate orange rootstocks were used. The trees grown in an orchard at Fukuoka Agricultural Research Center under customary field management in Japan were 22-24 year-old and in an alternate bearing cycle. Heavy fruit load trees with a good balance of vegetative and generative growth were selected in two on-years of the alternate bearing cycle, 2001 and 2003. In 2001, the effect of early fruit removal (on July 2) and a late harvest (December 11) on flowering was determined in comparison with trees harvested at commercial maturity (November 15; customary harvest). The defruited trees were also pruned in early-July, which caused a summer flush in mid-July. In 2003, the effect of three dates of harvest, namely October 15 (early harvest), November 18 (customary harvest) and January 14 in the next year (late harvest) on flowering was determined. Replicates consisted of three trees per treatment. Canopy volume of all trees was measured in November and calculated as described previously (Yahata et al., 2004).

\section{Flower-bud development in excised shoots}

From early-November to mid-March, 20 shoots (10$20 \mathrm{~cm}$ long) from each tree were sampled at two month intervals. Spring shoots were sampled from all trees except for the defruited trees, in which summer shoots were sampled. The shoots were defoliated and separated into two lots. One lot of 10 shoots was stored at $-80^{\circ} \mathrm{C}$ for carbohydrate analysis. The other 10 shoots were placed in a vase and sprayed with 100 ppm benzyladenine 
(BA) to force them into growth in a chamber kept at $28^{\circ} \mathrm{C}$ for the observation of flower-bud development (Yahata et al., 2004). After 8-14 days incubation, the new emerged shoots were tallied whether they were vegetative, mixed or generative. The results were expressed as number of shoots per 100 nodes.

During the following flowering season (in 2002 and 2004), 20 spring shoots which were $10-20 \mathrm{~cm}$ long and $1-1.5 \mathrm{~m}$ above the soil were selected at random from each tree (for the defruited trees 20 summer shoots were selected). The type of the newly sprouting shoots was counted in late-April.

\section{Carbohydrate analysis}

Extraction and quantification of soluble sugars and starch in the frozen shoot samples were performed according to our previous report (Yahata et al., 2004). Soluble sugars were extracted in $80 \%$ ethanol at $80^{\circ} \mathrm{C}$. After centrifugation, the supernatant was evaporated to the aqueous phase. An aliquot of the diluted solution was injected into an HPLC (LC-10A, Shimadzu Co.,
Kyoto, Japan) equipped with a refractive index detector. The residue after sugar extraction was resuspended in distilled water, and starch in the suspension was hydrolyzed by a combination of glucoamylase and maltase. After centrifugation and removal of the proteins, glucose content in the suspension was determined by a Somogyi-Nelson method. The starch content was calculated by multiplying the glucose content by 0.9 .

\section{Results}

Neither in 2001 nor in 2003-2004 were there found any significant differences in yield, either per tree or per canopy volume, among the trees harvested at different times (Table 1).

Most of the buds sprouted readily in a few days irrespective of the date of forcing, or the time of fruit harvest (Tables 2 and 3). Only vegetative shoots formed in November, except in the July-defruited trees in which a few mixed-type and generative shoots formed in the shoots developed after pruning (summer shoots). Both in the defruited trees (exp. in 2001) and the early

Table 1. Effects of harvest time on yield of 'Okitsu Wase'.

\begin{tabular}{|c|c|c|c|c|}
\hline Year & Treatment & Harvest date & Yield per tree $(\mathrm{kg} /$ tree $)$ & Yield per canopy volume $\left(\mathrm{kg} \cdot \mathrm{m}^{-3}\right)$ \\
\hline \multirow[t]{4}{*}{2001} & Early fruit removal & - & - & - \\
\hline & Customary harvest & Nov. 15 & $88.3 \pm 8.8^{z}$ & $4.01 \pm 0.2$ \\
\hline & Late harvest & Dec. 11 & $83.6 \pm 16.6$ & $3.72 \pm 0.1$ \\
\hline & & & NS & NS \\
\hline \multirow[t]{4}{*}{ 2003-2004 } & Early harvest & Oct. 15 & $124.0 \pm 12.4$ & $3.47 \pm 0.5$ \\
\hline & Customary harvest & Nov. 18 & $152.0 \pm 13.7$ & $3.64 \pm 0.2$ \\
\hline & Late harvest & Jan. 14 & $131.2 \pm 8.4$ & $3.64 \pm 0.1$ \\
\hline & & & NS & NS \\
\hline
\end{tabular}

NS indicates nonsignificant at $P=0.05$ by analysis of variance.

${ }^{\mathrm{z}}$ Mean $\pm \operatorname{SE}(\mathrm{n}=3)$.

Table 2. Effects of early fruit removal and harvest time on flower-bud development in excised shoots of 'Okitsu Wase'.

\begin{tabular}{|c|c|c|c|c|c|c|}
\hline \multirow{2}{*}{ Treatment } & \multirow{2}{*}{ Date of sampling ${ }^{z}$} & \multirow{2}{*}{$\begin{array}{l}\text { Percentage of bud } \\
\text { break nodes (\%) }\end{array}$} & \multicolumn{3}{|c|}{ Number of shoots formed per 100 nodes } & \multirow{2}{*}{$\begin{array}{l}\text { Number of flower } \\
\text { per } 100 \text { nodes }\end{array}$} \\
\hline & & & Vegetative & Mixed-type & Generative & \\
\hline \multirow[t]{3}{*}{ Early fruit removal } & Nov. 6 & $84.6 \pm 6.0^{y}$ & $54.2 \pm 10.8$ & $37.7 \pm 2.4$ & $7.4 \pm 2.4$ & $45.1 \pm 1.0$ \\
\hline & Jan. 7 & $100 \pm 0.0$ & $6.4 \pm 2.0$ & $120.3 \pm 7.1$ & $26.3 \pm 5.4$ & $146.6 \pm 5.2$ \\
\hline & Mar. 11 & $100 \pm 0.0$ & $4.4 \pm 2.9$ & $95.5 \pm 6.2$ & $95.5 \pm 9.7$ & $191.0 \pm 4.0$ \\
\hline \multirow[t]{3}{*}{ Customary harvest } & Nov. 6 & $98.9 \pm 1.1$ & $128.8 \pm 5.6$ & $0.0 \pm 0.0$ & $0.0 \pm 0.0$ & $0.0 \pm 0.0$ \\
\hline & Jan. 7 & $97.8 \pm 2.2$ & $128.5 \pm 3.6$ & $33.0 \pm 5.3$ & $1.1 \pm 1.1$ & $34.1 \pm 5.1$ \\
\hline & Mar. 11 & $100 \pm 0.0$ & $114.4 \pm 9.9$ & $88.9 \pm 8.7$ & $6.7 \pm 1.9$ & $95.6 \pm 10.6$ \\
\hline \multirow[t]{3}{*}{ Late harvest } & Nov. 6 & $100 \pm 0.0$ & $114.4 \pm 1.1$ & $0.0 \pm 0.0$ & $0.0 \pm 0.0$ & $0.0 \pm 0.0$ \\
\hline & Jan. 7 & $97.8 \pm 2.2$ & $107.4 \pm 9.5$ & $28.5 \pm 9.9$ & $3.3 \pm 1.9$ & $31.8 \pm 10.7$ \\
\hline & Mar. 11 & $100 \pm 0.0$ & $118.9 \pm 11.8$ & $62.2 \pm 4.0$ & $13.3 \pm 11.7$ & $75.5 \pm 11.6$ \\
\hline \multicolumn{7}{|c|}{ Significance } \\
\hline \multicolumn{2}{|c|}{ Treatment $(\mathrm{T})$} & NS & $* *$ & $* *$ & $* *$ & $* *$ \\
\hline \multicolumn{2}{|c|}{ Date of sampling (D) } & $*$ & $* *$ & $* *$ & $* *$ & $* *$ \\
\hline \multicolumn{2}{|c|}{ Interaction $(\mathrm{T} \times \mathrm{D})$} & $* *$ & $* *$ & $* *$ & $* *$ & $* *$ \\
\hline
\end{tabular}

$\mathrm{NS}, *$ and $* *$ indicate nonsignificant, significant at $P=0.05$ and $P=0.01$ by analysis of variance, respectively.

${ }^{\mathrm{z}}$ Sampled from November, 2001 to March, 2002.

y Mean $\pm \operatorname{SE}(\mathrm{n}=3)$. 
Table 3. Effects of harvest time on flower-bud development in excised shoots of 'Okitsu Wase'.

\begin{tabular}{|c|c|c|c|c|c|c|}
\hline \multirow{2}{*}{ Treatment } & \multirow{2}{*}{ Date of sampling ${ }^{z}$} & \multirow{2}{*}{$\begin{array}{c}\text { Percentage of bud } \\
\text { break nodes (\%) }\end{array}$} & \multicolumn{3}{|c|}{ Number of shoots formed per 100 nodes } & \multirow{2}{*}{$\begin{array}{c}\text { Number of flowers } \\
\text { per } 100 \text { nodes }\end{array}$} \\
\hline & & & Vegetative & Mixed-type & Generative & \\
\hline \multirow[t]{3}{*}{ Early harvest } & Nov. 4 & $81.6 \pm 7.6^{y}$ & $111.3 \pm 7.3$ & $0.0 \pm 0.0$ & $0.0 \pm 0.0$ & $0.0 \pm 0.0$ \\
\hline & Jan. 13 & $100 \pm 0.0$ & $96.6 \pm 15.7$ & $61.1 \pm 18.7$ & $6.4 \pm 3.2$ & $67.5 \pm 19.9$ \\
\hline & Mar. 15 & $97.6 \pm 2.4$ & $105.5 \pm 27.8$ & $117.8 \pm 16.4$ & $49.1 \pm 12.9$ & $166.9 \pm 23.6$ \\
\hline \multirow[t]{3}{*}{ Customary harvest } & Nov. 4 & $90.3 \pm 5.6$ & $123.2 \pm 10.5$ & $0.0 \pm 0.0$ & $0.0 \pm 0.0$ & $0.0 \pm 0.0$ \\
\hline & Jan. 13 & $100 \pm 0.0$ & $151.1 \pm 11.6$ & $2.2 \pm 1.1$ & $0.0 \pm 0.0$ & $2.2 \pm 1.1$ \\
\hline & Mar. 15 & $100 \pm 0.0$ & $223.3 \pm 11.6$ & $36.7 \pm 5.8$ & $1.1 \pm 1.1$ & $37.8 \pm 6.8$ \\
\hline \multirow[t]{3}{*}{ Late harvest } & Nov. 4 & $90.0 \pm 3.9$ & $125.5 \pm 9.1$ & $0.0 \pm 0.0$ & $0.0 \pm 0.0$ & $0.0 \pm 0.0$ \\
\hline & Jan. 13 & $97.8 \pm 1.1$ & $151.5 \pm 11.5$ & $1.1 \pm 1.1$ & $0.0 \pm 0.0$ & $1.1 \pm 1.1$ \\
\hline & Mar. 15 & $97.8 \pm 2.2$ & $233.3 \pm 7.7$ & $31.1 \pm 5.9$ & $0.0 \pm 0.0$ & $31.1 \pm 5.9$ \\
\hline \multicolumn{7}{|c|}{ Significance } \\
\hline \multicolumn{2}{|c|}{ Treatment $(\mathrm{T})$} & NS & $* *$ & $* *$ & ** & $* *$ \\
\hline \multicolumn{2}{|c|}{ Date of sampling (D) } & ** & $* *$ & ** & ** & ** \\
\hline \multicolumn{2}{|c|}{ Interaction $(\mathrm{T} \times \mathrm{D})$} & NS & $* *$ & $* *$ & $* *$ & $* *$ \\
\hline
\end{tabular}

NS and ** indicate nonsignificant and significant at $P=0.01$ by analysis of variance, respectively.

${ }^{z}$ Sampled from November, 2003 to March, 2004.

${ }^{y}$ Mean $\pm \operatorname{SE}(n=3)$.

harvested trees (exp. in 2003) flower formation occurred earlier than in the customary harvested and late harvested trees, as seen in the January sampling. By mid-March, flower formation was 2-fold (exp. in 2001) and 5-fold higher (exp. in 2003) in the defruited and early harvested trees in comparison with the other two treatments. The early fruit removal caused a rapid decrease of the vegetative shoots and a marked increase of the mixedtype shoots from November to January, then the generative shoots increased by mid-March. There was no significant difference in the total number of flowers between the customary and late harvested trees throughout the investigation period.

In early-November, the starch content in the summer shoots of the defruited trees was higher than in the fruiting trees (Table 4). Starch accumulation in the spring shoots of the early harvested trees also started earlier by mid-January than in the customary and late harvested trees (Table 5). In the customary and late harvested trees, the starch contents in the spring shoots raised after January to a high level in March, both in 2002 and 2004. The early fruit removal resulted in a higher sugar level during November than in the customary and late harvested trees (exp. in 2001 and 2003). In the two years, the sugar contents became maximal by the January sampling, then decreased by the March sampling coinciding with the accumulation of starch (Tables 4 and 5). During January and March no effect on sugar

Table 4. Effects of early fruit removal and harvest time on starch and sugar contents in shoots of 'Okitsu Wase'.

\begin{tabular}{|c|c|c|c|c|}
\hline \multirow{2}{*}{ Treatment } & \multirow{2}{*}{ Date of sampling ${ }^{z}$} & \multirow{2}{*}{ Starch content $\left(\mathrm{mg} \cdot \mathrm{g}^{-1} \mathrm{FW}\right)$} & \multicolumn{2}{|c|}{ Sugar content $\left(\mathrm{mg} \cdot \mathrm{g}^{-1} \mathrm{FW}\right)$} \\
\hline & & & Sucrose & Total $^{y}$ \\
\hline \multirow[t]{3}{*}{ Early fruit removal } & Nov. 6 & $22.3 \pm 1.7^{\mathrm{x}}$ & $15.7 \pm 1.0$ & $43.3 \pm 2.6$ \\
\hline & Jan. 7 & $14.2 \pm 0.3$ & $27.0 \pm 1.8$ & $75.1 \pm 3.0$ \\
\hline & Mar. 11 & $77.7 \pm 1.7$ & $11.3 \pm 0.2$ & $23.8 \pm 0.3$ \\
\hline \multirow[t]{3}{*}{ Customary harvest } & Nov. 6 & $3.9 \pm 0.3$ & $15.4 \pm 0.8$ & $35.6 \pm 3.4$ \\
\hline & Jan. 7 & $6.8 \pm 0.5$ & $32.0 \pm 1.0$ & $77.2 \pm 0.7$ \\
\hline & Mar. 11 & $80.9 \pm 0.7$ & $23.1 \pm 0.8$ & $37.6 \pm 0.6$ \\
\hline \multirow[t]{3}{*}{ Late harvest } & Nov. 6 & $3.7 \pm 0.3$ & $17.5 \pm 1.5$ & $36.8 \pm 1.6$ \\
\hline & Jan. 7 & $4.5 \pm 0.1$ & $32.5 \pm 0.3$ & $66.0 \pm 1.0$ \\
\hline & Mar. 11 & $75.7 \pm 1.2$ & $24.2 \pm 1.8$ & $36.1 \pm 2.0$ \\
\hline \multicolumn{5}{|l|}{ Significance } \\
\hline Treatment $(\mathrm{T})$ & & $* *$ & $* *$ & NS \\
\hline Date of sampling (D) & & $* *$ & $* *$ & $* *$ \\
\hline Interaction $(\mathrm{T} \times \mathrm{D})$ & & $* *$ & $* *$ & $* *$ \\
\hline
\end{tabular}

NS and $* *$ indicate nonsignificant and significant at $P=0.01$ by analysis of variance, respectively.

z Sampled from November, 2001 to March, 2002.

${ }^{y}$ Expressed as the sum of sucrose, glucose, fructose and sorbitol contents.

${ }^{x}$ Mean $\pm \operatorname{SE}(n=3)$. 
Table 5. Effects of harvest time on starch and sugar contents in shoots of 'Okitsu Wase'.

\begin{tabular}{|c|c|c|c|c|}
\hline \multirow{2}{*}{ Treatment } & \multirow{2}{*}{ Date of sampling ${ }^{z}$} & \multirow{2}{*}{ Starch content $\left(\mathrm{mg} \cdot \mathrm{g}^{-1} \mathrm{FW}\right)$} & \multicolumn{2}{|c|}{ Sugar content $\left(\mathrm{mg} \cdot \mathrm{g}^{-1} \mathrm{FW}\right)$} \\
\hline & & & Sucrose & Total $^{\mathrm{y}}$ \\
\hline \multirow[t]{3}{*}{ Early harvest } & Nov. 4 & $8.7 \pm 1.1^{x}$ & $17.9 \pm 0.8$ & $32.5 \pm 1.3$ \\
\hline & Jan. 13 & $20.2 \pm 0.9$ & $30.3 \pm 0.4$ & $57.8 \pm 0.9$ \\
\hline & Mar. 15 & $73.2 \pm 1.2$ & $15.5 \pm 0.4$ & $17.5 \pm 0.2$ \\
\hline \multirow[t]{3}{*}{ Customary harvest } & Nov. 4 & $2.1 \pm 0.2$ & $12.2 \pm 0.4$ & $20.9 \pm 0.3$ \\
\hline & Jan. 13 & $6.2 \pm 0.3$ & $26.5 \pm 0.7$ & $58.9 \pm 2.1$ \\
\hline & Mar. 15 & $61.0 \pm 0.6$ & $22.2 \pm 1.2$ & $25.7 \pm 1.5$ \\
\hline \multirow[t]{3}{*}{ Late harvest } & Nov. 4 & $2.5 \pm 0.2$ & $12.5 \pm 0.6$ & $20.4 \pm 1.1$ \\
\hline & Jan. 13 & $4.6 \pm 0.4$ & $27.2 \pm 0.5$ & $54.9 \pm 0.8$ \\
\hline & Mar. 15 & $62.3 \pm 2.2$ & $22.3 \pm 1.1$ & $25.3 \pm 1.2$ \\
\hline \multicolumn{5}{|l|}{ Significance } \\
\hline Treatment $(\mathrm{T})$ & & $* *$ & NS & NS \\
\hline Date of sampling (D) & & $* *$ & $* *$ & $* *$ \\
\hline Interaction $(\mathrm{T} \times \mathrm{D})$ & & $* *$ & $* *$ & $* *$ \\
\hline
\end{tabular}

NS and ** indicate nonsignificant and significant at $P=0.01$ by analysis of variance, respectively.

${ }^{z}$ Sampled from November, 2003 to March, 2004.

${ }^{y}$ Expressed as the sum of sucrose, glucose, fructose and sorbitol contents.

${ }^{x}$ Mean $\pm \operatorname{SE}(n=3)$.

Table 6. Effects of early fruit removal and harvest time on number of newly sprouting shoots and flowers in shoots of 'Okitsu Wase' at next flowering period in spring.

\begin{tabular}{|c|c|c|c|c|c|c|}
\hline \multirow{2}{*}{ Year } & \multirow{2}{*}{ Treatment } & \multirow{2}{*}{$\begin{array}{c}\text { Percentage of bud } \\
\text { break nodes }(\%)\end{array}$} & \multicolumn{3}{|c|}{ Number of shoots formed per 100 nodes } & \multirow{2}{*}{$\begin{array}{l}\text { Number of flowers } \\
\text { per } 100 \text { nodes }\end{array}$} \\
\hline & & & Vegetative & Mixed-type & Generative & \\
\hline \multirow[t]{4}{*}{2002} & Early fruit removal & $88.6 \pm 3.0^{z}$ & $0.0 \pm 0.0$ & $6.6 \pm 1.7$ & $135.0 \pm 3.3$ & $141.6 \pm 4.3$ \\
\hline & Customary harvest & $63.9 \pm 1.2$ & $26.2 \pm 3.4$ & $29.9 \pm 2.0$ & $17.4 \pm 3.9$ & $47.3 \pm 3.8$ \\
\hline & Late harvest & $59.5 \pm 2.9$ & $23.1 \pm 0.8$ & $30.7 \pm 1.2$ & $10.2 \pm 2.4$ & $40.9 \pm 3.4$ \\
\hline & & ** & $* *$ & $* *$ & $* *$ & $* *$ \\
\hline \multirow[t]{4}{*}{2004} & Early harvest & $69.6 \pm 9.0$ & $8.4 \pm 3.9$ & $42.7 \pm 9.7$ & $54.9 \pm 3.7$ & $97.6 \pm 13.3$ \\
\hline & Customary harvest & $55.0 \pm 0.4$ & $54.1 \pm 5.8$ & $11.4 \pm 2.5$ & $3.5 \pm 0.6$ & $14.9 \pm 2.1$ \\
\hline & Late harvest & $54.7 \pm 2.0$ & $61.2 \pm 4.1$ & $8.5 \pm 1.1$ & $1.8 \pm 0.5$ & $10.3 \pm 1.5$ \\
\hline & & NS & $* *$ & $* *$ & $* *$ & $* *$ \\
\hline
\end{tabular}

NS and $* *$ indicate nonsignificant and significant at $P=0.01$ by analysis of variance, respectively.

${ }^{\mathrm{z}}$ Mean $\pm \operatorname{SE}(\mathrm{n}=3)$.

contents among the treatments was detected.

During the following flowering season (in 2002 and 2004 ), the percentage of sprouting nodes was $88.6 \%$ in the summer shoots of the defruited trees, and in the 54.7$69.6 \%$ range in the spring shoots of the other treatments (Table 6). No vegetative and many generative shoots were observed in the defruited trees in 2002. Also, the early fruit harvest resulted in a large increase in the number of flowering shoots and the proportion of few vegetative shoots. No significant difference in the number of flowers was observed between the customary and late harvested trees, in which the number of flowering shoots was markedly less than those of the other two treatments.

\section{Discussion}

Flower formation in citrus trees occurs in response to chilling temperature (Moss, 1969; Southwick and Davenport, 1986). Flower induction in satsuma mandarin trees has been reported to occur gradually from October to January (Garcia-Luis and Kanduser, 1995). In this study, some flowering shoots formed in early-November on the excised summer shoots which flushed after fruit removal and pruning in July. The total number of flowers became maximal in these trees in early-January. In contrast, in the excised spring shoots of the other treatments, all shoots that emerged in early-November were vegetative. In these trees, the flower induction seemed to be retarded in comparison with the summer shoots flushed after fruit removal and pruning in July. The presence of fruit load largely reduces flower formation in citrus trees (Garcia-Luis et al., 1986; Valiente and Albrigo, 2004), so that the flowering response to the low temperature is more marked for buds of defruited trees (Garcia-Luis and Kanduser, 1995).

It has been reported that the fruits exerted a timedependent inhibitory effect on flowering, so that a significant proportion of flower inhibition takes place 
before November (Garcia-Luis et al., 1986; Iwasaki, 1959; Ogata et al., 1996). In the heavy fruit load trees used in this study, the timing of a rapid increase of flower formation was clearly affected by the harvest time. In the trees harvested in mid-October, an increase in flower-forming buds was observed from January to March. In contrast, in the trees harvested late, flower induction progressed more slowly and the number of flowers was at anytime significantly lower than that of the early harvested trees. Similar results on the flower formation were obtained in a previous study with three satsuma mandarin cultivars which matured at different times (Yahata et al., 2004). These results suggest that the progression of flower induction during the rest period was accelerated by an earlier harvest in comparison with the customary and late harvests. In addition, there was no significant difference in the total number of flowers between the customary and late harvested trees. Ringing the trees before the winter rest period increased flowering the following spring, but not when done after November (Agusti et al., 1992; Iwahori et al, 1990). It seems that the presence of fruit load after that moment had no further effect on flower formation.

Flower formation and yield have been found to have positive correlation with carbohydrate levels (Jones et al., 1970; Okada, 2004), especially starch (Goldschmidt and Golomb, 1982; Jones et al., 1974). A clear relation between the number of flowers and sugar contents in the shoots could not be found in the present study, although starch accumulation seemed to parallel flower induction. The removal of fruits increases starch content and flowering in citrus trees (Goldschmidt et al., 1985; Jones et al., 1974). In the very-early maturing cultivar, earlier harvesting in late-October induced rapid accumulation of starch in spring shoots, resulting in a progressive flower formation compared with the cultivars harvested after mid-November (Yahata et al., 2004). Our data in Wase satsuma mandarin indicate a clear effect of the fruit harvest before November on both flower formation and starch accumulation. These results provide some insight into the mechanism of alternate bearing and the importance of harvest timing for the stable production of fruit. Carbohydrates levels are not always a limiting factor for flowering of citrus (GarciaLuis et al., 1995; Goldschmidt et al., 1985), and the involvement of endogenous gibberellins has been indicated (Ogata et al., 1996; Yahata et al., 1995). It seems important to clarify the complex effects of carbohydrate and plant hormone levels such as gibberellin on flower formation.

\section{Literature Cited}

Agusti, M., V. Almela and J. Pons. 1992. Effects of girdling on alternate bearing in citrus. J. Hort. Sci. 67: 203-210.

Garcia-Luis, A., V. Almela, C. Monerri, M. Agusti and J. L. Guardiola. 1986. Inhibition of flowering in vivo by existing fruits and applied growth regulators in Citrus unshiu. Physiol. Plant. 66: 515-520.

Garcia-Luis, A., F. Fornes and J. L. Guardiola. 1995. Leaf carbohydrates and flower formation in Citrus. J. Amer. Soc. Hort. Sci. 120: 222-227.

Garcia-Luis, A. and M. Kanduser. 1995. Changes in dormancy and sensitivity to vernalization in axillary buds of satsuma mandarin examined in vitro during the annual cycle. Ann. Bot. 76: 451-455.

Garcia-Luis, A., M. Kanduser, P. Santamarina and J. L. Guardiola. 1992. Low temperature influence on flowering in Citrus. The separation of inductive and bud dormancy releasing effects. Physiol. Plant. 86: 648-652.

Goldschmidt, E. E., N. Aschkenazi, Y. Herzano, A. A. Schaffer and S. P. Monselise. 1985. A role for carbohydrate levels in the control of flowering in citrus. Sci. Hort. 26: 159166.

Goldschmidt, E. E. and A. Golomb. 1982. The carbohydrate balance of alternate-bearing citrus trees and the significance of reserves for flowering and fruiting. J. Amer. Soc. Hort. Sci. 107: 206-208.

Inoue, H. 1990. Effects of temperature on bud dormancy and flower bud differentiation in satsuma mandarin. J. Japan. Soc. Hort. Sci. 58: 919-926 (In Japanese with English summary).

Iwahori, S., A. Garcia-Luis, P. Santamarina, C. Monerri and J. L. Guardiola. 1990. The influence of ringing on bud development and flowering in satsuma mandarin. J. Exp. Bot. 41: 1341-1346.

Iwasaki, T. 1959. Studies on the differentiation and development of the flower bud in citrus. Bull. Tokai-Kinki Agr. Expt. Stn. Hort. 5: 1-76 (In Japanese with English summary).

Jones, W. W., T. W. Embleton, E. L. Barnbart and C. B. Cree. 1974. Effect of time and amount of fruit thinning on leaf carbohydrates and fruit set in Valencia oranges. Hilgardia 42: 441-449.

Jones, W. W., T. W. Embleton, M. L. Steinacker and C. B. Cree. 1970. Carbohydrates and fruiting of 'Valencia' orange trees. J. Amer. Soc. Hort. Sci. 95: 380-381.

Moss, G. I. 1969. Influence of temperature and photoperiod on flower induction and inflorescence development in sweet orange (Citrus sinensis L. Osbeck). J. Hort. Sci. 44: 311-320.

Ogata, T., H. Hasukawa, S. Shiozaki, S. Horiuchi, K. Kawase, I. Iwagaki and H. Okuda. 1996. Seasonal changes in endogenous gibberellin contents in satsuma mandarin during flower differentiation and the influence of paclobutrazol on gibberellin synthesis. J. Japan. Soc. Hort. Sci. 65: 245-253 (In Japanese with English summary).

Okada, M. 2004. Effectiveness of reserved nutrients for estimating productivity of satsuma mandarin. J. Japan. Soc. Hort. Sci. 73: 163-170 (In Japanese with English summary).

Southwick, S. M. and T. L. Davenport. 1986. Characterization of water stress and low temperature effects on flower induction in citrus. Plant Physiol. 81: 26-29.

Valiente, J. I. and L. G. Albrigo. 2004. Flower bud induction 
of sweet orange trees [Citrus sinensis (L.) Osbeck]: effect of low temperatures, clop load, and bud age. J. Amer. Soc. Hort. Sci. 129: 158-164.

Yahata, D., K. Matsumoto and K. Ushijima. 2004. Relationship between flower-bud differentiation and carbohydrate contents in spring shoots of very-early, early and late maturing cultivars of satsuma mandarin. J. Japan. Soc.
Hort. Sci. 73: 405-410.

Yahata, D., Y. Oba and M. Kuwahara. 1995. Changes in carbohydrate levels, $\alpha$-amylase activity, indoleacetic acid and gibberellin-like substances in the summer shoots of Wase satsuma mandarin trees grown indoors during flower-bud differentiation. J. Japan. Soc. Hort. Sci. 64: 527-533 (In Japanese with English summary).

\author{
ワセウンシュウの収穫期の相違が花芽形成と枝中の炭水化物含量に及ぼす影響 \\ 矢羽田第二郎・松本和紀・牛島孝策 \\ 福岡県農業総合試験場８18-8549 筑紫野市吉木
}

收穫期の相違と 7 月の早期全摘果がワセウンシュウ “興津早生”の切り枝から発生する花らい数と炭水化物含 量に及ぼす影響を調査した。秋冬季まで結果させた樹の 春枝では，秋季の花成誘導が早期全摘果樹の夏枝に比べ て遅れることが示唆された. 早期全摘果樹と早期収穫樹 （10 月中旬）では秋冬季の花芽形成が促進され，切り枝 の花らい数が 3 月中旬まで顕著に増加した. 一方，慣行
収穫樹（11 月中旬）や晚期収穫樹（12 月中旬，1 月中 旬）の春枝は花らいの発生が少なく，1 月以降徐々に増 加した. 早期全摘果樹と早期収穫樹は，11 月中旬以降に 収穫した樹に比べて秋冬季に結果母枝のデンプン含量が 顕著に増加した． ワセウンシュウでは 11 月中旬以降の 結果負担により春枝のデンプン集積が劣り，秋冬季に形 成される花芽数も少なくなるものと考元られた. 